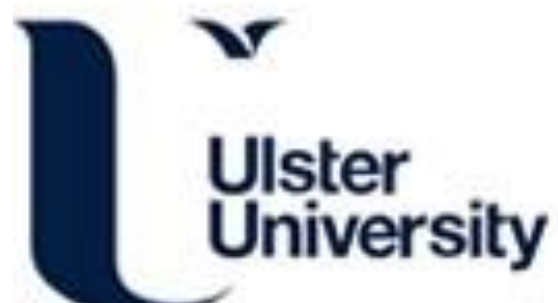

\section{Cultural nationalism, Gaelic Sunday and the Gaelic Athletic Association in early twentieth century Ireland}

McGuire, A., \& Hassan, D. (2012). Cultural nationalism, Gaelic Sunday and the Gaelic Athletic Association in early twentieth century Ireland. The International Journal of the History of Sport, 29(6), 912-923.

https://doi.org/10.1080/09523367.2011.631702

Link to publication record in Ulster University Research Portal

\section{Published in:}

The International Journal of the History of Sport

Publication Status:

Published (in print/issue): 15/02/2012

DOI:

10.1080/09523367.2011.631702

\section{Document Version}

Publisher's PDF, also known as Version of record

\section{General rights}

Copyright for the publications made accessible via Ulster University's Research Portal is retained by the author(s) and / or other copyright owners and it is a condition of accessing these publications that users recognise and abide by the legal requirements associated with these rights.

\section{Take down policy}

The Research Portal is Ulster University's institutional repository that provides access to Ulster's research outputs. Every effort has been made to ensure that content in the Research Portal does not infringe any person's rights, or applicable UK laws. If you discover content in the Research Portal that you believe breaches copyright or violates any law, please contact pure-support@ulster.ac.uk. 
This article was downloaded by: [University of Ulster at Coleraine]

On: 15 February 2012, At: 06:43

Publisher: Routledge

Informa Ltd Registered in England and Wales Registered Number: 1072954 Registered

office: Mortimer House, 37-41 Mortimer Street, London W1T 3J H, UK

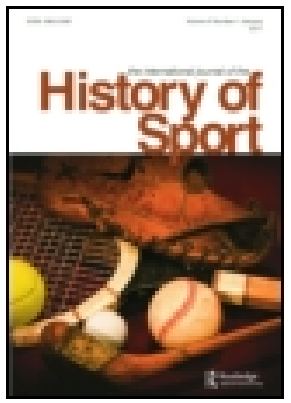

\section{The International J ournal of the History of Sport}

Publication details, including instructions for authors and subscription information:

http:// www. tandfonline.com/loi/ fhsp20

\section{Cultural nationalism, Gaelic Sunday and the Gaelic Athletic Association in early twentieth century Ireland}

Andrew McGuire ${ }^{a} \&$ David Hassan ${ }^{a}$

a Ulster Sports Academy, University of Ulster, J ordanstown, Belfast, UK

Available online: 15 Feb 2012

To cite this article: Andrew McGuire \& David Hassan (2012): Cultural nationalism, Gaelic Sunday and the Gaelic Athletic Association in early twentieth century Ireland, The International J ournal of the History of Sport, DOI: 10.1080/ 09523367.2011.631702

To link to this article: http:// dx.doi.org/ 10.1080/09523367.2011.631702

\section{iFirst}

\section{PLEASE SCROLL DOWN FOR ARTICLE}

Full terms and conditions of use: http://www.tandfonline.com/page/terms-andconditions

This article may be used for research, teaching, and private study purposes. Any substantial or systematic reproduction, redistribution, reselling, loan, sub-licensing, systematic supply, or distribution in any form to anyone is expressly forbidden.

The publisher does not give any warranty express or implied or make any representation that the contents will be complete or accurate or up to date. The accuracy of any instructions, formulae, and drug doses should be independently verified with primary sources. The publisher shall not be liable for any loss, actions, claims, proceedings, demand, or costs or damages whatsoever or howsoever caused arising directly or indirectly in connection with or arising out of the use of this material. 


\title{
Cultural nationalism, Gaelic Sunday and the Gaelic Athletic Association in early twentieth century Ireland
}

\author{
Andrew McGuire and David Hassan* \\ Ulster Sports Academy, University of Ulster, Jordanstown, Belfast, UK
}

To date, much of the established historical literature on the Gaelic Athletic Association (GAA), the governing body of Gaelic games in Ireland, has focused on the potential or perceived political agency of the organisation. To this end, great swathes of work that has centred on early twentieth century Ireland has also examined the extent of the relationship the GAA had with other nationalist bodies in the country at that time, such as the Irish Republican Brotherhood (IRB), or at the very least the role of GAA members who were also part of such groups. However, the GAA failed in fact to adopt any official 'political' position during this period, albeit with one notable exception - a mass demonstration that came to be referred to as 'Gaelic Sunday'. The example of Gaelic Sunday will be used during the course of this article to demonstrate the actual position of the GAA during this time and in so doing temper the pervasive view abroad, one that the GAA is perhaps too willing to acquiesce with, that it somehow played something close to a defining role in the broader political and revolutionary pursuit of partial independence for Ireland. Rather, as this article will confirm, the GAA's role within early twentieth century Irish society, whilst undoubtedly revealing it to be a powerful nationalist body, remained nevertheless much more cultural than political in nature.

Keywords: Gaelic Athletic Association; Irish cultural nationalism; Gaelic Sunday; Irish independence; Royal Irish Constabulary

\section{Nationalisme culturel, dimanche gaélique et Association Athlétique Gaélique en Ireland au début du vingtième siècle}

Jusqu'à présent, la littérature historique établie sur l'Association Athlétique Gaélique (GAA), l'instance dirigeante des jeux gaéliques en Ireland, s'est centrée sur l'action politique potentielle ou perçue de l'organisation. A cette fin, un vaste ensemble de travaux qui se sont intéressés à l'Irlande du début du vingtième siècle ont également étudié le développement des relations de la GAA avec d'autres instances nationalistes du pays à cette époque, tel que la Confrérie républicaine irlandaise (IRB) ou du moins le rôle des membres de la GAA qui appartenaient aussi à ces organisations. Toutefois, la GAA n'est en fait pas parvenue à adopter une position politique officielle à cette époque, à une exception remarquable près: une démonstration de masse connue comme le Dimanche gaélique. L'exemple du Dimanche gaélique sera choisi au cours de cet article pour démontrer la position de la GAA et, se faisant, de tempérer le regard insidieux que l'on peut avoir de l'extérieur, voire même de l'intérieur de la GAA, qui voit dans cette manifestation un élément qui joue éventuellement un rôle plus large dans le projet politique et révolutionnaire d'indépendance de l'Ireland. Au contraire, comme cet article le confirmera, le rôle de la GAA dans la société irlandaise du vingtième siècle, bien

*Corresponding author. Email: d.hassan@ulster.ac.uk 
que reflétant une organisation nationaliste puissante, fut plus culturel que politique par nature.

Mots-clés: l'Association Athlétique Gaélique; Nationalisme culturel irlandais; Dimanche gaélique; indépendance irlandaise; édit royal irlandais

\section{EInacionalismo cultural, el Gaelic Sunday y la Gaelic Athletic Association en la Irlanda de principio del siglo $\mathrm{XX}$}

Hasta ahora, gran parte de la historiografía hegemónica sobre la Gaelic Athletic Association (GAA), el órgano de gobierno de los juegos gaélicos en Irlanda, se ha centrado en analizar la actuación política potencial o percibida de esta organización. Con este objetivo in mente, una gran variedad de trabajos sobre la Irlanda de principios del siglo XX también han estudiado las relaciones de la GAA con otras organizaciones nacionalistas, como la Irish Republican Brotherhood (IRB), o si más no el papel desempeñado por los miembros de la GAA que también formaban parte de estos grupos. No obstante, la GAA de hecho no adoptó ninguna postura "política" durante este periodo, con una notable excepción: una manifestación masiva que acabó siendo bautizada como el "Gaelic Sunday". Utilizaremos el ejemplo del Gaelic Sunday en este artículo para demostrar la verdadera postura de la GAA durante este periodo, con lo que matizaremos la opinión, bastante extendida fuera de Irlanda y con la que parece que la GAA se siente cómoda, que de alguna manera esta organización desempeñó algo parecido a un papel definitorio en el empeño político y revolucionario más amplio para conseguir la independencia parcial de Irlanda. Lo que en realidad ocurrió, tal y como se confirma en este artículo, es que el papel de la GAA en el marco de la sociedad irlandesa de principio del siglo XX, si bien la convirtió en una organización nacionalista potente, tuvo una naturaleza mucho más cultural que política.

Palabras clave: Gaelic Athletic Association; nacionalismo cultural irlandés; Gaelic Sunday; independencia de Irlanda; policía real irlandesa

\section{Kulturnationalismus, Gälischer Sonntag und die Gaelic Athletic Association im Irland des frühen zwanzigsten Jahrhunderts}

Bis heute hat sich ein Großteil der Standardliteratur über die Gaelic Athletic Association (GAA), dem Dachverband der gälischen Spiele in Irland, auf das Potenzial oder auf die vermeintliche politische Vertretung dieser Organisation konzentriert. In diesem Kontext haben sich viele Studien, die sich mit Irland zu Beginn des zwanzigsten Jahrhunderts beschäftigen, auch mit dem Ausmaß der Verbindungen der GAA mit anderen nationalistischen Organisationen Irlands wie der Irish Republican Brotherhood (IRB) - zu dieser Zeit auseinandergesetzt oder zumindest die Rolle derjenigen GAA-Mitglieder untersucht, die Teil dieser Gruppierungen waren. In jedem Fall hat es die GAA in diesem Zeitraum mit einer Ausnahme nicht geschafft, eine offizielle "politische" Position einzunehmen. Diese bemerkenswerte Ausnahme ist eine Massendemonstration, die als „Gälischer Sonntag“ bezeichnet wurde. Anhand des Gälischen Sonntags wird in diesem Artikel die tatsächliche Position des GAA während dieser Zeit aufgezeigt. Damit soll die, vor allem im Ausland, weit verbreitete Ansicht korrigiert werden, nach der die GAA eine bestimmende Rolle im allgemeinen, politischen und revolutionären Streben nach teilweiser Unabhängigkeit für Irland gespielt habe. Diese Sicht wird natürlich auch gerne von der GAA selbst eingenommen. Demgegenüber wird dieser Artikel zeigen, dass die GAA in der irischen Gesellschaft im frühen zwanzigsten Jahrhundert zwar zweifellos ein starker nationalistischer Verband war, aber dennoch viel mehr kultureller als politischer Natur war.

Schlagworte: Gaelic Athletic Association, Irischer Kulturnationalismus; Gälischer Sonntag; Irische Unabhängigkeit; Royal Irish Constabulary 
文化民族主义、盖尔人的星期天和盖尔运动协会在二十世纪早期的爱尔兰

迄今为止, 许多已有的历史文献在论述作为爱尔兰体育运动主管部门的盖尔运动协会 (GAA) 时, 都将其描述为一 种潜在的或是能被感知为政治代理的组织机构。为此，很多反映二十世纪早期爱尔兰的相关研究检验了盖尔运动协 会与民族主义团体之间的关系, 比如爱尔兰共和兄弟会 (IRB ) 以及那些盖尔运动协会的成员加入爱尔兰共和兄弟 会所扮演的角色。然而，事实上盖尔运动协会在此期间所选择的任何形式的官方的政治姿态都以失败而告终，尽管 有一个显著的例外。这个例外的事件是后来被称为盖尔人星期天的大规模示威游行。盖尔人星期天的案例被本文所 采用，用来论述盖尔运动协会在当时的实际作用，同时也用来考证一个已有的关于盖尔运动协会所普遍接受的观点 , 即它在某种程度上扮演了一个广泛追求爱尔兰政治和革命独立过程中近乎决定性的角色。而本文将要证实的却是 ，虽然盖尔运动协会母庸置疑在二十世纪早期的爱尔兰社会所扮演的角色展示了其作为一个强大的民族主义团体的 角色，然而它却在本质上保留了比政治意义更多得文化含义。

关键词 : 盖尔运动协会; 爱尔兰文化民族主义; 盖尔人星期天; 爱尔兰独立; 皇家爱尔兰警察

\section{Introduction}

The purpose of this article is to address a partial shortcoming in the existing historical narrative concerning the Gaelic Athletic Association (GAA) in pre-independence Ireland. Though much attention has been paid to the events of the Easter Uprising and Bloody Sunday, and the degree to which the GAA was involved, the events of Gaelic Sunday, which occurred between these two undoubtedly more high-profile events, have been largely overlooked. Indeed, Gaelic Sunday provides something of a test case for the official attitudes of the GAA at the time, which is somewhat lacking amid examinations of the events around the Easter Uprising and Bloody Sunday. Though the GAA and its members were involved in both of the aforementioned events, the Association took no official stance or action on either. This has led some to question the degree to which the GAA had direct involvement in these incidences and instead to consider the extent to which activity ascribed to the GAA was merely the actions of men who happened to be GAA members acting independently of the Association or under the flag of convenience held by some other Nationalist organisations. This is a question debated at some length by Irish historians and one that continues to be expounded upon to this day. However, in the events surrounding Gaelic Sunday, the GAA and the British authorities in Ireland were engaged in a highly contentious political dispute that revealed the GAA's position through its defined and explicit actions. This direct interaction has garnered little attention from historians, especially when compared to that afforded other, more well-known, events including those detailed above. One of the principle aims of this article, therefore, is to compile accounts of Gaelic Sunday in order to complete a full narrative of the events surrounding that day and to place this analysis in the larger context of preindependence Irish history.

By using a range of contemporary sources, such as Parliamentary papers, GAA resolutions and newspaper accounts, this article will seek to recreate the circumstances that led to Gaelic Sunday and from there explore the actions of the GAA to better understand its position and role during this volatile period in Ireland's history. This article will seek to reveal the position of the GAA through its own actions, rather than attempt to infer the position of the GAA through the activities of portions of its membership who were acting independently of the Association itself. It will be shown that while the GAA avoided any explicit political 
associations in Ireland, it was nonetheless a Nationalist organisation, practicing a type of nationalism that could best be described as cultural, rather than political and certainly not radical. At times, this cultural nationalism required forays into the political arena, but it will be argued that this was not the main goal of the GAA and that it better served the people of Ireland in its cultural capacity.

\section{Gaelic Sunday}

That the GAA played a significant role in Irish society in the early part of the twentieth century is quite clear, though to what extent it did so in the political realm is a matter of some debate. As previously mentioned, this article puts forward the idea that the role of the GAA was overwhelmingly a cultural one and not some political adjunct to the activities of others. To help illustrate the importance of the GAA as a normal part of life for the Irish population, a debate in 1914 regarding a proposed 'Day of Rest' bill shines a light on the concerns politicians had for their constituents should they be prevented from playing Gaelic games. Sir Edward Goulding, MP for Worcester, explained to the Chief Secretary for Ireland Edward Shortt the role Sunday recreation played in Irish society. The bill up for consideration before Parliament, which Goulding himself supported, was designed to enshrine in law a day of rest for workers across Ireland and Britain. During debate on the bill, Goulding explained what he felt the role of the GAA was in Irish society and the adverse affect not being able to play Gaelic games on Sunday would have:

In regard to entertainments on Sunday, the position in Ireland is altogether different from the position in England. There they treat Sunday on entirely different principles from those on which we treat it here, and this Gaelic Athletic Association has been going on for years, and every one of us, whether or not we believe in the faith of the majority of the people in Ireland, are convinced that the Gaelic Athletic Association does great good in Ireland. ${ }^{1}$

As Goulding had argued before Parliament, the GAA was seen to be a pan-Irish association. 'Faith' was not a prerequisite for membership in the GAA, nor was political affiliation, at least as far as the Nationalist organisations with which individuals otherwise acquainted themselves with were concerned. While the GAA did ban functionaries of the British armed forces and police, it did not prohibit members from claiming affiliation with the Irish political party of their choosing. Goulding worried that if the mandatory day of rest bill was granted that Irish society, particularly the working classes, would be adversely affected as the entertainment provided by the GAA would be deemed in violation of the new bill.

Thomas Lundon, MP for Limerick East, received a letter from the GAA Central Council expressing its worries regarding the bill. Speaking before the House of Commons, Lundon shared the content of the letter, along with his views:

On behalf of the Gaelic Athletic Association, I write to draw your attention to the wording of a Sub-section which appears in the Weekly Rest-day Bill down for Second Reading in the House of Commons tomorrow. The following is the Sub-section referred to: To carry on, advertise, engage in, or be present at, any public performance, spectacle, exhibition, game, contest, competition, or other entertainment of whatever kind at which any fee or payment is charged or demanded, directly or indirectly, either for admission to such entertainment or for the use of any place or seat within or in the neighbourhood of the hall, theatre, enclosure, etc. 
We think that if that were carried into effect, it would virtually entirely suppress all Sunday sport, and, of course, you as an old member know this would wipe out our association altogether, because we are able to play the national pastimes only on Sundays. We are convinced, even if this Bill does not apply to Ireland, it will have illeffects, because we know, as a fact, that the Gaelic Athletic Association in Great Britain is composed of our kith and kin, and is growing stronger and stronger every day. ${ }^{2}$

As a long-standing member of the GAA, Lundon was against the bill in its entirety because of the spread of the GAA to places like 'London, Glasgow, Liverpool, Cardiff, and elsewhere', places where Irish immigrants would not be exempt from the bill, even if Ireland itself was granted an exemption, and would not be allowed to play 'the games of their country and of their forefathers'. Lundon concluded his remarks saying, 'I hope no Irishman will assist in putting it [the bill] on the Statute Book'. The opposition to the bill was more than just an opposition to the general distaste for British rule in Ireland. Through this bill, the Irish legislators saw their country's national pastimes at stake. The GAA had become 'the most powerful national organisation in Ireland', according to Lundon. ${ }^{3}$ Goulding and Lundon's positions do show how the GAA was viewed by some as a positive force in Irish society and why it was worth exempting from the ban on gatherings. Despite the good intentions of the bill's sponsors, to ensure that their constituents would have adequate protection under the law regarding their right to a have a day off work, some of the Irish section of Parliament fought the bill which they considered detrimental to a vital part of their cultural identity.

Though the Day of Rest debate was an interesting introduction into the role of the GAA in wider society, and offers a valuable perspective, these are ultimately the words of politicians sitting in parliament in Westminster and not of the GAA itself. For that, the events that would become known as 'Gaelic Sunday' are a much more direct way to discern the actions and approach of the GAA. On 4 July 1918, a proclamation was signed into effect by Lt. Gen. Frederick Shaw, Commander in Chief of the British forces in Ireland, which prohibited 'the holding or taking part in any meetings, assemblies, or processions within the whole of Ireland'. ${ }^{4}$ Concerns arose almost immediately among the indigenous Irish. Newspapers reported that meetings of the Gaelic league and workers' unions were banned by police under the proclamation. MPs for Ireland were concerned they would not be able to address large gatherings of their constituents in the discharge of their official duties as democratically elected representatives of the people.

William Doris, MP for Mayo West, claimed that he received notice that he 'should not address a meeting of his constituents', a charge which Secretary Shortt denied. But Shortt did suggest that it was possible that the MP had been instructed to seek a permit before doing so. ${ }^{5}$ John Dillon, MP for neighbouring Mayo East, immediately challenged Shortt on this point, asking whether he would introduce law into this country - that no member can address his constituents without a permit? Is that the democratic liberty for which we are all on to fight? ${ }^{6}$ The ability of the Irish population to hold any sort of assembly was under considerable doubt due to the proclamation, and Irish MPs struck out at the accord as a consequence.

John Devlin, MP for Belfast West, gave an impassioned speech before the House of Commons against the proclamation. In his speech, Devlin asked,

Is it the law which makes it treasonable to play Gaelic games because they say they are political? Is it the law which says it is treasonable to hold hurling matches? ... Is it the 
law that football matches, athletic sports, Gaelic festivals, Irish concerts are to be held only if the local police and military permit? ${ }^{7}$

While Devlin was speaking in rhetorical tones, MP for Wicklow West John Donovan asked very pointed questions of Secretary Shortt in response to reports that GAA matches had been interfered with by police. Donovan asked Shortt

Whether, in the view of the fact that the Gaelic Athletic Association was not within the category of organisation recently proclaimed as illegal in Ireland, will he say why the police authorities banned the playing of football and hurling matches under the auspices of this body except with the special permission of the authorities. ${ }^{8}$

Shortt replied that 'any gathering which comes within the regulation requires a permit, which is always granted in the case of bona fide sports or entertainment'. Shortt's answer begins to reveal the government's position of being sceptical about the true intent of the GAA, a scepticism borne of a long held mistrust of the Association being a purely sporting one. Two years prior to this, in response to some special trains for GAA matches being cancelled, the Athlone City Council passed a resolution that said, in part, that such inconsiderate, unnecessary and provocative actions of this nature can have but one effect - a feeling of bitterness towards English administration in the country'. ${ }^{10}$ As tensions between the GAA and the British authorities in Ireland continued to climb, the resolution of the Athlone City Council looked increasingly prescient.

At times, the confrontation between the GAA and police reached violent levels. The Nenagh Guardian outlined one such account of a football match in Banagher, Co. Offaly. Though the match had not been advertised ahead of time, a small contingent of police was present at the pitch as the game started and cautioned the players against holding the game in question. The match proceeded as planned until the halftime interval, when District Inspector Knox arrived with further police backup and some soldiers. Several people were injured by police batons as the armed forces charged the field; players and spectators beat a hasty retreat over an adjacent fence and down a road leading back into the nearby town. ${ }^{11}$

Similar confrontations were reported across Ireland during this period. Police charged the crowd assembled to watch a football match in Ballymena, Co. Antrim ${ }^{12}$ and, at the other end of Ireland, attacked the players assembled to take the pitch at a match in Co. Kerry. ${ }^{13}$ Spectators' and players' names were taken down by police at a junior football match in Castleblaney, Co. Monaghan. ${ }^{14}$ Indeed, police interference in Gaelic matches went so far as to arrest nine young boys playing a match in Phoenix Park, Dublin. ${ }^{15}$

As the debate in Parliament ensued, likewise the GAA continued to measure its response to such increased pressure from the police. A GAA delegate met with the authorities at Dublin Castle where it was spelled out in very specific terms that "no hurling or football matches would be allowed ... unless a permit was obtained'. Understanding that the GAA would be required under the law to seek permits for any matches it wished to hold, the Central Council unanimously decided that "no permit be asked for under any conditions'. This decision was relayed to provincial and county boards, along with notice that no individuals should apply for permits either. The Central Council warned that 'any individual or club infringing the foregoing order becomes automatically and indefinitely suspended'. A date of 
4 August 1918 was set on which Gaelic matches would be held simultaneously across Ireland, all without the application for a permit being sought. ${ }^{16}$

At this juncture, the authorities were forced to react to the GAA's plans, continuing the tit-for-tat political posturing in which the two parties had become locked. One option available was a mass mobilisation of police and military troops to try to oppose as many matches as possible, keeping in line with previous conduct. However, this option had the potential for large scale and wide-spread rioting and violence. Rather than potentially incite civil unrest, the government decided to reconsider its stance on Gaelic matches being played.

Throughout the first week of August, newspaper reports outlined the government's new position on Gaelic matches. It came to light that the authorities sent a circular around to the police outlining how Gaelic matches were no longer considered to fall under the restrictions of the proclamation. ${ }^{17}$ Previous police interference in matches was said by Secretary Shortt to have been a result of police who 'had unfortunately misunderstood their instructions'. ${ }^{18}$ The move by the government to reconsider was applauded by some outsiders. The Manchester Guardian ran an editorial praising the decision, saying that 'what the consequences of the police and military interference with that enormous number of fixture might have been many people here would prefer not to think about'. ${ }^{19}$ Indeed, the consequences feared by the Manchester Guardian of just such a confrontation would unfortunately be realised two years later at Croke Park on what has since been infamously referred to as 'Bloody Sunday'.

John Dillon had a much more cynical reaction to the news of a police stand down. As part of a larger speech before Parliament, Dillon outlined the frustrations of the Irish people under the proclamation. To Dillon, the enforcement of a ban on social gatherings and public meetings was 'greatly to the annoyance of the people of Ireland, where the feeling is extremely bitter and exasperated'. Dillon was slightly incredulous of the government reconsidering its stance and that a 'curious telephonic mistake', which led to the misunderstanding under which the police had prevented meetings in Ireland from taking place, was only rectified after the announcement of plans for Gaelic Sunday. ${ }^{20}$

Once the desired effect of the authorities reversing their position in light of the plans for Gaelic Sunday had been realised, what incentive was there for the GAA to carry on with their games? The answer may be found in an editorial in the Meath Chronicle that said that 'every Irish man and woman worth of the name is expected to patronise in some practical manner their national pastimes'. ${ }^{21}$ Gaelic Sunday was to be used as a show of cultural nationalism so that the authorities might know not only the seriousness with which the GAA viewed the ban on Gaelic games, but also the sheer numbers of people and the clout which it had at its disposal. The importance of Gaelic games within society necessitated that those who treasured Irish culture take the opportunity to stand with the GAA.

The organisational structure of the GAA was central to its success. At its most basic, amongst its grassroots, the GAA is organised along parish lines. This very parochial integration with the community ensures that local people are embroiled directly with the GAA. At its elite level, the GAA has a strong Central Council administrative body, which is able to dictate matters of policy to the four provincial and 32 county boards in Ireland. The ability of the GAA to effectively disseminate decisions from the Central Council to the parish-level clubs is shown by the number of matches organised for Gaelic Sunday and in numerous examples in the intervening, almost century-long, period of GAA activity. That is not to say that 
at all times the relationship between the Central Council and county boards was so harmonious. Problems did occur at times between the two, often when the county boards resented what they saw as interference in local affairs by the 'far-away' Central Council in Dublin. However, in the case of Gaelic Sunday, the usefulness of the organisational structure as it stood at the time came to the fore.

On Gaelic Sunday the North Tipperary Board organised no less than 16 matches in 16 different locations across the county, which were to be 'whole-heartedly carried out'. ${ }^{22}$ County Cavan organised 17 matches and County Monaghan 27, as reported by the Anglo Celt. ${ }^{23}$ In Meath, the Gaelic Sunday activities were to be incorporated into the annual harvest festival for the Patron of Kieran. ${ }^{24}$

On the day, over 1500 hurling, football and camogie matches were played across Ireland. With two teams competing in each match, nominally 15 players per team, it reveals that over 45,000 athletes took part in Gaelic Sunday, to say nothing of the number of spectators who showed their support by patronising games as suggested by the editorial in the Meath Chronicle. All of these matches were played without permits, and virtually all without interference from the police. The matches in counties Meath, Cavan, Monaghan and Tipperary (discussed above) were all carried out as planned, even with heavy rain in Tipperary. ${ }^{25}$ Similarly, bad weather forced the cancellation of another 40 matches in Co. Cork. ${ }^{26}$ In a most interesting hurling match, a team of priests and a team of Christian Brothers competed in Kilkee, Co. Clare. ${ }^{27}$

Almost no police interaction was reported on Gaelic Sunday. In Athlone, two RIC officers and a 'large number of soldiers' were present at a match. However, these men were in attendance as paying spectators rather than in any official capacity under the law. ${ }^{28}$ Similarly, in Kilruane, Co. Tipperary, a police sergeant and constable sought admission to a match being played, only to be informed that only paying spectators were allowed within the stadium grounds. Rather than either pay or force their way into the match, the two men instead elected to watch from the street adjacent to the grounds. ${ }^{29}$ The sole police action taken in Dublin on Gaelic Sunday was only tangentially related to the games being played. Fourteen boys, aged between 12 and 17, were taken into police custody for selling flags on the street. The boys' names and addresses were taken down by the police and they were allowed to go home without charge. ${ }^{30}$

Across Ireland, Gaelic Sunday was carried off to great success. Not a single match was impeded or cancelled due to outside interference by the police or military. The only exception to this rule were cancellations due to inclement weather, as in Co. Cork. The RIC and military did not attempt to interfere with any of the matches played, in accordance with their new orders from Dublin Castle. Commenting upon the proclamation, the Manchester Guardian decried the ban on Gaelic games as being a 'stupid attempt to confound all forms of Nationalist activity, legitimate and illegitimate, under one ban as seditious' ${ }^{31}$ The Enniscorthy GAA Board passed a resolution congratulating the Central Council for the 'effective means it had devised for defeating the attempt that had been made to crush the GAA out of existence'. ${ }^{32}$

The widespread success of Gaelic Sunday is testament to the organisational strength of the GAA and the confidence county board and clubs had placed in their fellow athletes. In an era when long-distance travel and communication was difficult, and occasionally made even more troublesome by the British authority's periodic restrictions on train travel, it is quite remarkable that plans with such breadth were carried off as successfully as they were. The GAA's top-down organisational structure, under the direction of the all-powerful Central Council, was the key to this 
success. Rather than the provincial or county boards each organising a number of uncoordinated protest matches, the Central Council was able to make, distribute and enforce a decision for the entire country. No records exist that show a subordinate board acting counter to the resolution of the Central Council. In the absence of the Central Council, it would not be a stretch to imagine the disjointed results that would have been achieved had the county boards acted without coordination or the difficulty in successfully executing such a plan should they attempt to do so.

Even with such a strong Central Council to enact plans for a nationwide Gaelic Sunday, it was up to each county board to organise and play the matches that had been set for that day. That so many matches across the whole of Ireland were played simultaneously shows the confidence each local GAA board had in every other to do the same. With telephone access limited and postal services taking several days, local boards had no way to quickly contact others to learn of their plans. Instead, each local board took it on faith that every other would also be following the resolution of the Central Council. The confidence each constituent part of the GAA had in every other element in regards to following through with the plans for Gaelic Sunday was exemplified in the effort that each took to stage as many matches as they did. As an article in the Irish Times captured when considering the overall results of Gaelic Sunday, 'it might be said that the GAA had an easy victory, but the victory had great significance as showing what the people could accomplish by unity of purpose and determination'. 33

\section{Conclusion}

The GAA has played a prominent role in Irish society since its founding in 1884 as a promoter of Gaelic games and broader cultural pursuits. The GAA, through games such as hurling and Gaelic football, allows for the promotion of a particularly cultural form of Irish nationalism. This is a means for people to express an Irish identity in a manner that is non-violent and non-political. Through its nationwide organisation, the GAA allows Irish people across the country to simultaneously participate in the same sports, providing a unifying influence.

Indeed the GAA was founded with the expressed goal of preserving and promoting Irish culture through the national games and language. In this manner, the GAA practiced a form of cultural nationalism that differentiated it from the more politically-based nationalist movements of the time. One could make a statement in support of an Irish identity through hurling or football without explicitly adopting a position for or against Home Rule, Fenianism or any other political pronouncement. Of course, this does not preclude any member of the GAA holding or expressing his or her own views in private. What the GAA did was provide a forum for Irish men and women to come together in pursuit of a common goal, regardless of their personal view, at a time when such platforms were few and far between.

Dominant historiography has largely ignored the events of Gaelic Sunday. Rather, previous works have sought to place the GAA within the high-profile events of the Easter Uprising and Bloody Sunday, outcomes of which no doubt greatly impacted upon the path of Irish history. However, the GAA took no direct role in either happening, notwithstanding the blood soaked events at Croke Park that prematurely brought an end to the challenge game between Dublin and Tipperary at Croke Park. Instead, high-profile GAA members who also were involved in 
revolutionary activities have reinforced an erroneous perception that the Association played an active role, both in popular thought and historical research, in the affairs of early twentieth century Ireland. Gaelic games provided men like Michael Collins with practical experience in leadership and organisational skills, which in some quarters has been extrapolated into the theory that the GAA was itself an active organisation for independence, at least in the physical force perception of the idea.

However, the mistake has been made to attribute the beliefs and actions of individuals to the GAA and its entire membership. Merely having revolutionaries in its ranks does not a revolutionary organisation make; a charge the GAA has too readily been accused of in the past. Despite the GAA's repeated statements to the contrary, as well as their non-political actions, the British government refused to acknowledge the Association in any other light than the one which painted it as a politically nationalist body in league with the Irish Republican Brotherhood (IRB) or some other nationalist groupings. This is not to say that the GAA failed to adopt political stances on certain issues, merely that the degree to which the GAA was involved in politics has been over-emphasised at times and in some quarters. This broad characterisation of the GAA has failed to take into account its many levels of membership and the different attitudes of each, something this article has sought to address. While the GAA contained a small number of men who would fight for Ireland, the association and its members were not taking up arms on any grand scale. The decision to participate in the events of Easter Week, and indeed less noteworthy events before and after this defining moment in Irish history, was an entirely personal one, not one dictated by the GAA. As this article has shown, Gaelic Sunday is a useful test case for being able to reveal the GAA directly engaging with the British authorities and asserting itself in the political landscape. Rather than teasing insights from events in which the GAA's involvement is unclear at best, this article has taken a direct approach and in doing so has helped accurately complete the story of the GAA in pre-independence Ireland.

In moving forward with this line of inquiry regarding the role of the GAA in Irish society at the time in question, deficiencies in this article would present fertile opportunities for greater research. In particular, the lack of a county-by-county analysis around the degree to which each county board participated in Gaelic Sunday would certainly be of interest. Future research would benefit greatly from the ability to compare counties on an individual basis in order to draw greater conclusions about the participation in and effectiveness of Gaelic Sunday as it pertains to disparate locations within Ireland. Anecdotal evidence would suggest that counties in the North would be less inclined to partake in a mass protest than their Southern counterparts, and indeed the examples in this article are disproportionally Southern in their focus, due in part to the existence of available sources. This county-by-county data and analysis would allow future research to draw much more forceful conclusions. Thus while this article has focused on a broader, nation-wide picture of the events of Gaelic Sunday, there are undoubtedly worthy articles to be completed for each of the 32 counties around this defining period in the GAA's history.

\section{Notes on contributors}

Andrew McGuire is a graduate of Trinity College Dublin and an expert in twentieth century Irish history. He has written widely on the role of the Gaelic Athletic Association (GAA) in Ireland and abroad and recently delivered a paper on this subject at the $2011 \mathrm{NASSH}$ 
Conference in Austin. An American national, Andrew is currently working in Europe where he continues to research the early history of sport in Ireland.

David Hassan is a Senior Lecturer in Sport at the Ulster Sports Academy. Dr Hassan's work on the social, political and historical role of the GAA in Ireland and abroad spans more than 12 years and has resulted in a range of outputs including academic journal articles, edited collections, book chapters and conference presentations.

\section{Notes}

1. House of Commons, Weekly Rest-Day Bill, col. 2227.

2. Ibid., col. 2274-5.

3. Ibid.

4. Dublin Castle, Order.

5. House of Commons, Meetings, col. 1979.

6. Ibid.

7. House of Commons, Mr. Dillon's Motion, col. 45.

8. House of Commons, Meetings, col. 1978.

9. Ibid.

10. Chief Secretary's Office, Hayden to Duke, CSO 1916 Rising 5644/25633.

11. 'Ban on Irish Games', Nenagh Guardian, July 27, 1918, 2.

12. 'Irish Prohibitions', Irish Independent, July 30, 1918, 3.

13. Bureau of Military History, Horgan.

14. 'Irish Prohibitions', Irish Independent, July 30, 1918, 3.

15. 'Proclamation and Irish Games', Manchester Guardian, July, 31 1918, 4.

16. GAA, Memo, July 22, 1918.

17. 'Proclamation and Irish Games', Irish Independent, August 1, 1918, 3.

18. 'Irish Sports: Ban Removed', Manchester Guardian, July 31, 1918, 4.

19. Ibid.

20. House of Commons, Ireland, col. 1641.

21. 'The Patron of Kieran', Meath Chronicle, August 3, 1918, 6.

22. 'Gaelic Sunday', Nenagh Guardian, August 3, 1918, 4.

23. 'Athletics and Sports', Anglo-Celt, August 3, 1918, 5.

24. 'The Patron of Kieran', Meath Chronicle, August 3, 1918, 6.

25. 'Gaelic Games All over Ireland', Irish Independent, August 5, 1918, 3.

26. 'Taking over of Public Offices: Permits for Religious Gatherings!' Irish Independent, August 6, 1918, 1.

27. 'A Novel Hurling Match', Irish Independent, August 8, 1918, 3.

28. 'Gaelic Games All over Ireland', Irish Independent, August 5, 1918, 3.

29. 'Taking Over of Public Offices: Permits for Religious Gatherings!' Irish Independent, August 6, 1918, 1.

30. 'Gaelic Sunday', Irish Times, August 5, 1918, 4.

31. 'The Irish Proclamation: A Stupid Confusion', Manchester Guardian, August 13, 1918, 4.

32. 'News of The Week: Provincial', Weekly Irish Times, August 17, 1918, 3.

33. Ibid.

\section{References}

'Athletics and Sports', Anglo-Celt, August 3, 1918, 5.

'Ban on Irish Games', Nenagh Guardian, July 27, 1918, 2.

Bureau of Military History, 'Maurice Horgan Witness Statement', WS 953, National Archives of Ireland.

Chief Secretary's Office, 'Hayden to Duke, 23 Nov. 1916', 1916 Rising Collection CSO 5645/ 25633, National Archives Ireland.

Dublin Castle Records, 'Order under Defence of the Realm Regulation 9AA', CO904/92/169/2, The National Archives (microfilm, National Archives Ireland).

'Gaelic Games all over Ireland', Irish Independent, August 5, 1918, 3.

'Gaelic Sunday', Irish Times, August 5, 1918, 4.

'Gaelic Sunday', Nenagh Guardian, August 3, 1918, 4. 
House of Commons, 'Weekly Rest-Day Bill', Sessional Papers, 1914, Orders of the Day, 22 May 1914, vol. 62, col. 2223-2301.

House of Commons, 'Mr. Dillon's Motion', Sessional Papers, 1918, Government of Ireland, 29 July 1918, vol. 109, col 45-201.

House of Commons, 'Ireland', Sessional Papers, 1918, Adjournment of the House (Autumn), 8 August 1918, vol. 109, col. 1636-1666.

House of Commons, 'Meetings (Permits)', Sessional Papers, 1918, Ireland, 25 July 1918, vol. 108, col. 1978-1979.

'Irish Proclamation, A Stupid Confusion', Manchester Guardian, August 13, 1918, 4.

'Irish Prohibitions', Irish Independent, July 30, 1918, 3.

'Irish Sports: Ban Removed', Manchester Guardian, July 31, 1918, 4.

'News of The Week: Provincial', Weekly Irish Times, August 17, 1918, 3.

'Novel Hurling, Match A', Irish Independent, August 8, 1918, 3.

'Patron of Kieran, The', Meath Chronicle, August 3, 1918, 6.

'Proclamation and Irish Games', Manchester Guardian, July 31, 1918, 4.

'Proclamation and Irish Games', Irish Independent, August 1, 1918, 3.

'Taking over of Public Offices: Permits for Religious Gatherings!' Irish Independent, August 6, $1918,1$. 